\title{
Portable Electronics and Trends in Goods Stolen from the Person
}

\begin{abstract}
Objectives: To better understand theft of portable electronic goods this study examined the type of goods stolen during theft and robbery in England and Wales over almost two decades. Methods: Using all sweeps of the Crime Survey for England and Wales between 1994 and 2010/11 the proportion of incidents where a particular item was stolen was calculated, then compared over time. Results: A small range of items accounted for the bulk of what was taken, namely cash, purses/wallets, credit/debit cards and mobile phones. Conclusions: Considerable changes to the stolen goods landscape were found, with a shift from more traditional items such as cash and purses/wallets to portable electronic items such as mobile phones. Recommendations are made for preventing the loss of the items most frequently stolen during offences of theft and robbery.
\end{abstract}

Suggested key words: theft from the person; robbery; Crime Survey for England and Wales; mobile phones; stolen goods; hot products.

\section{$\underline{\text { Introduction }}$}

Attention-grabbing media headlines claim mobile phone theft has soared - "Smartphone ${ }^{1}$ thefts are driving an epidemic of violent crime" (CITEworld 10 ${ }^{\text {th }}$ May 2013; Roman and Chalfin 2007). This comes against a backdrop of dramatic falls in a number of crime types over the last 20 years (van Dijk et al. 2005; Zimring 2007; Rosenfeld 2009; van Dijk, Tseloni and Farrell 2012). Between 1995 and 2010/11, total crime captured by the Crime Survey for England and Wales (CSEW, formerly the British Crime Survey or BCS) fell 50 per cent (Chaplin, Flatley and Smith 2011). Although declining, trends in theft from the person and robbery were generally flat compared to the peak and steep declines seen for other crime types (see Figure 1). Findings from the 2004/05 International Crime Victims Survey (ICVS) suggest trends in 
"pickpocketing", unlike other types of property crime, showed no consistent downward trend across the countries surveyed (van Dijk, van Kesteren and Smit 2007).

FIGURE 1 ABOUT HERE

This study examines why theft and robbery have not declined as steeply as other crime types. It is hypothesized that the trend in theft and robbery is composed of two underlying trends: one which mirrors the more general decreases in crime, and one which reflects increased theft arguably due to the greater availability of new, valuable goods (particularly mobile phones) that are attractive to thieves and/or carried on the person.

The analysis reported here focuses on theft from the person and robbery of personal property: "...where the goods stolen belong to an individual or group of individuals, rather than a corporate body..." (Home Office 2015: 4). Theft from the person refers to the theft of an item or items directly from the victim without the use of physical force. Robbery involves the use or threat of force or violence to steal from a victim.

Major social and technological developments create new opportunities for offenders, in terms of environments, targets, information sources and tools (Ekblom 2005). Cohen and Felson (1979) partly attributed the increase in residential burglary during the 1970s to the proliferation of lightweight electronic goods. With many of these desirable goods now carried on an individual's person the central role of theft from the person and robbery is emphasized. The possibility that product availability has influenced overarching crime trends in England and Wales is thus a focus of this paper. 


\section{$\underline{\text { Previous Research }}$}

A growing, but still relatively limited, number of studies have examined the items stolen during particular offences to ascertain whether some products are more prone to being stolen than others (Clarke 1999; Wellsmith and Burrell 2005; Fitzgerald and Poynton 2011; Shaw et al. 2015). Exploring the attributes of frequently stolen products can provide an insight into the "craft" of thieves, in particular their motives, skills and disposal methods (Pires and Clarke 2011). This information can assist in designing effective crime prevention policies.

To the author's knowledge, this is the first study to explore items stolen during thefts from the person and robberies in England and Wales over this time period. With few exceptions, research in this area falls into one of five categories focusing upon either: aggregate crime data; other crime types, for example household burglary (Budd 1999; Wellsmith and Burrell 2005; Fitzgerald and Poynton 2011; Hardison Walters, Moore and Berzofsky 2013; Shaw et al. 2015); a time period insufficient for commenting upon the attractiveness of products to thieves before and after the crime drop (Clarke 1999); police recorded crime data for specific localities (Barker et al. 1993; Kock, Kemp and Rix 1996; Smith 2003; Gentry 2015); or the theft trajectory of particular products, such as mobile phones (Mailley et al. 2008; Office for National Statistics (ONS) 2013; Home Office 2014).

One of the most widely cited scholars in this field, Ronald Clarke, devised the acronym

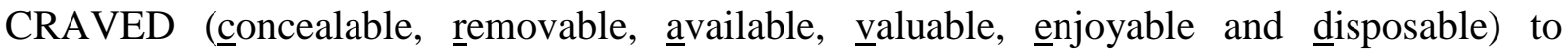
summarize the attributes of goods most vulnerable to theft (Clarke 1999). A number of similar conclusions can be drawn from previous research that are, on the whole, consistent with his hypothesis. Thieves appear to concentrate their efforts upon removable, easily disposed of items (Wellsmith and Burrell 2005; Fitzgerald and Poynton 2011), with cash heralded as the 
ultimate hot product (Clarke 1999; Felson 1998). Handbags/briefcases, purses/wallets and electrical items are also routinely stolen, with the most common justifications for their selection lying in their ease of disposal and, in many cases, ready conversion to cash or drugs (Clarke 1999; Nelson, Collins and Gant 2002; Palmer, Holmes and Hollin 2002; Schneider 2005).

Previous research suggests the ease with which an offender can dispose of stolen goods is a key factor in their decision-making process. Ease of disposal is influenced by a variety of factors with demand for a product on the legitimate market said to influence its positioning in the stolen goods market and subsequent theft (Sutton 1995; Budd 1999; Wellsmith and Burrell 2005). Felson $(1997$; 1998) claims new products go through a life cycle of four stages: innovation; growth; mass market; and saturation. In the innovation stage products are relatively unknown and feature much less on both the legitimate and illegitimate markets. Theft levels are said to be highest during periods of growth and mass market appeal. By saturation point products are widely available, widely owned and relatively inexpensive thus reducing their attractiveness to thieves. Both CRAVED (Clarke 1999) and the life cycle hypothesis (Felson 1997 ; 1998) act as useful theoretical starting points for this research.

From a practical perspective, theft from the person and robbery victimization can have a significant physical and emotional impact upon a victim (Gale and Coupe 2005). This begins with any injuries sustained during the incident and associated medical costs. In addition, mobile phones and laptops can contain a wealth of (often sentimental) data (Lifestyle Services Group 2011, cited in Home Office 2014). Misuse of confidential data may also mean the victim experiences further crime as a result of the initial incident, for example identity theft (Ekblom 2014a). The relative lack of research into theft from the person and robbery combined with the 
potential emotional, physical and financial consequences of victimization are viewed as sufficient justification for this research.

\section{$\underline{\text { Research Questions }}$}

This study addresses the following three research questions:

1. With regards to theft from the person and robbery offences, are particular products stolen more frequently than others and, if so, what are they?

2. Have there been changes in the products targeted through these crimes since 1993 ?

3. Do trends in products stolen adhere to the "life cycle hypothesis"?

\section{$\underline{\text { Data }}$}

The CSEW is a face-to-face victimization survey widely regarded as the most comprehensive long-term measure of crime trends in England and Wales. The survey was first conducted in 1982 and from then was run approximately every two years until 2001 when it became a continuous survey. The CSEW provides a consistent measure of particular crimes and collects a wealth of information on the respondent, their household and area of residence as well as (where appropriate) detailed information regarding experiences of crime ${ }^{2}$. Data of this kind largely avoids issues relating to non-reporting and police recording practices. This is particularly important in relation to theft from the person and robbery where the value and type of items stolen may influence whether or not a victim chooses to report the incident to the police (Shaw et al. 2015). Fourteen sweeps of the CSEW from 1994 to 2010/11 (Home Office) were analyzed.

\section{Stolen Goods Variables}

With regard to goods stolen, the CSEW asks: "Was any property stolen, or taken without permission, even if the victim later got it back?" Questions concerning the items stolen are then 
only asked of respondents who complete the long Victim Module ${ }^{3}$ which asks: "Could you tell me what was actually stolen, even if you later got it back?" This is a multiple response categorical variable therefore allowing respondents to report the theft of more than one item per incident. The month and year of victimization were used to compute a new semester of victimization variable to pinpoint the six-month period ${ }^{4}$ when the incident occurred. The creation of this variable allows for more direct comparisons with consumer data. The proportion of incidents (in a given time period) where a particular item was stolen is reported.

\section{$\underline{\text { Results }}$}

Results are reported under the three research questions guiding the study.

Research Question 1: Are particular products stolen more frequently than others and, if so, what are they?

Wellsmith and Burrell (2005) define a "hot product" as an item stolen in over 25 per cent of incidents under a particular legal category. In adopting this definition, four hot products were identified namely cash, purses/wallets, credit/debit cards and mobile phones. Cash and purses/wallets were consistently the hottest products for these crime types, alternately occupying the top two positions over time (see Figure 2$)^{5}$.

\section{FIGURE 2 ABOUT HERE}

\section{Research Question 2: Have there been changes in the products targeted through theft and} robbery since $1993 ?$

Figure 2 charts the changing trajectory of goods stolen since 1993. Table 1 shows the percentage change in the proportion of incidents where particular items were stolen between two six-month periods in 1996 and 2010 (January-June). These time periods were chosen as 
they constitute the highest and lowest years (respectively) of risk of theft and robbery victimization (Thompson 2014).

\section{TABLE 1 ABOUT HERE}

\section{Cash}

The theft of cash decreased from its peak in July-December 1997 where it was stolen in 73 per cent of incidents. When comparing figures from January-June 1996 with its equivalent sixmonth period in 2010 we see a statistically significant reduction in the theft of cash by 19 per cent. There was a particularly marked decrease of 11 per cent from July 2008 to June 2010 . The theft of cash in 2010 reduced to levels seen prior to 1995.

\section{Purse/Wallet}

Perhaps unsurprisingly the theft of purses/wallets follows a very similar trend to cash, peaking in the six-month period of January-June 1997 (stolen in 65 per cent of incidents). Comparing figures from January-June 1996 with January-June 2010 we see a reduction of 3 per cent, although this should be viewed as part of a much larger decline in purse/wallet theft since 1995 .

\section{Credit/Debit Cards}

The theft of credit/debit cards peaked in July-December 2005 where they were stolen in 36 per cent of incidents. The lowest value is seen in July-December 1993 ( 7 per cent of incidents) and increases thereafter. When comparing figures from 1996 to 2010 there is a reduction of 2 per cent, although the broader trend shows a steady increase from 1993 until 2005. Thefts of cards then decline (with fluctuations) from 2005.

\section{Mobile Phones}

Theft of mobile phones shows the biggest increase of all products over the period of study, peaking in January-June 2004 where they were stolen in 35 per cent of incidents. A direct 
comparison of figures from the first half of 1996 with the equivalent period in 2010 shows an increase of 25 per cent.

\section{Other Products}

When comparing figures from the first half of 1996 with those from 2010, we see a decline in the theft of more traditional products, for example checkbooks (12 per cent reduction) and documents ( 8 per cent fall) (see Table 1 and Figure 3). This forms part of a wider decline over the full period for these items. The theft of checkbooks peaked in 1996 (stolen in 13 per cent of incidents), with negligible numbers in recent years. Thefts of documents have fallen with fluctuations from year to year, peaking at 17 per cent in the first half of 1995. A number of items, including MP3 players, computer equipment and cameras, were consistently stolen in less than 10 per cent of incidents across the period studied.

\section{FIGURE 3 ABOUT HERE}

\section{Research Question 3: Do trends in products stolen through theft and robbery adhere to the}

\section{"life cycle hypothesis"?}

It is clear there has been an evolution of hot products over time. Without knowledge of the number of targets in circulation over the period studied (or a suitable proxy measure), it is not possible to accurately establish product theft risk. In an attempt to explore the relationship between ownership levels and theft, mobile phone ownership data is taken from the General Lifestyle Survey (GLS) (formerly the General Household Survey). The GLS ran continuously from 1971 until 2012, collecting a wide range of information from private households in Great Britain (UK Data Service 2016). Figure 4 shows an approximate 35 per cent increase in the theft of mobile phones over the period studied alongside a corresponding increase in the proportion of individuals who own a mobile phone. 


\section{FIGURE 4 ABOUT HERE}

\section{$\underline{\text { Discussion }}$}

Findings show concentration of efforts on a smaller range of products than has been found in previous empirical research, suggesting two potential conclusions:

1. These items are routinely carried on the person - emphasizing the importance of Clarke's (1999) concepts of removability and availability; and/or

2. Thieves specifically target these items (not opportunistic) and are thus a reflection of the tastes of thieves (and the wider population) and the value of the item on the stolen goods market.

It is likely that stolen goods trends reflect elements of each of the above. For some purposes, the distinction does not matter - efforts should be concentrated upon reducing theft of the items most frequently taken. To this end, we must develop a better understanding of why particular products may be more vulnerable to theft.

\section{Payment Preferences}

Changes in the way UK consumers receive and dispense of their money may hold some explanatory power in understanding trends in items stolen. The increase in popularity of online shopping (ONS 2015), credit/debit card use and the advent of new technology in the form of contactless payments ${ }^{6}$ has transformed the way goods are paid for. In 2010 cash was used in 59 per cent of all transactions, a decline from almost three quarters ( 73 per cent) ten years previously (Payments Council 2010). With the vast majority receiving their wages directly into a bank account (ibid), the decline in "cash in hand" payments may have led to less cash circulating within society or, more specifically, carried on the person. 
Over one-third (approximately 37 per cent on average across sweeps) of incidents involved the theft of a purse/wallet and cash. Given the tendency to carry cash and credit cards within a purse or wallet, it may be that purses/wallets act as motivators in terms of their potential contents. The introduction of Chip and PIN in the UK in 2004 and its mandatory status from February 2006 was designed to reduce card theft and fraud. Since 2006, the proportion of incidents where cards were stolen has, on the whole, decreased alongside total fraud losses on UK cards (Financial Fraud Action UK 2012). Vulnerability to theft and robbery victimization may be reduced, and exposure limited, due to: a. more sophisticated measures to combat card theft; and b. only withdrawing/carrying cash intended to be used in the immediate future.

\section{Mobile Phones}

Figure 2 shows a marked increase in the theft of mobile phone handsets from 1996 until peaking in 2004. Rank ordering the top five items stolen by six-month period, mobile phones first appeared in the top five in July-December 1999. This coincides with what some term the 1999 "tipping point" (Computer Networking and Telecommunications Research (CNTR) 2013) with more than four million mobile phones sold in the UK in the last three months of that year (BBC News $5^{\text {th }}$ January 2000).

Mobile phone handsets have changed dramatically since the early 1990s. One of the first commercially available, mass-produced handsets, the Nokia 1011, was released in November 1992 weighing approximately $17 \mathrm{oz}$ and with the following dimensions: 6.9 × 2.4 x 1.4 inches (CNTR 2013). By contrast the Apple iPhone 5s weighs approximately 4oz and has dimensions of $4.9 \times 2.3 \times 0.3$ inches (Apple Inc. 2015). This is quite a dramatic reduction in overall size with the iPhone a quarter of the weight and smaller in volume, thus more portable. 
Manufacturers routinely bring new and updated handsets to the market, leading consumers to invest in upgrades (Mailley, Whitehead and Farrell 2006). The average price of a mobile phone increased rapidly between 2001 and 2003 (Shaw et al. 2015). The "hybridization" (Kaplankiran et al. 2008) of mobile phones, whereby more and more technology is packed into a handset, fuels high market turnover. This often means handset prices remain high and market saturation is seldom, if ever, reached (Mailley, Whitehead and Farrell 2006). Mobile phones appear to be locked in the phases of mass market and growth. It may be that the traditional product lifecycle does not apply particularly well to such fast moving and dynamic markets. It might therefore be more appropriate to suggest that particular makes and models of mobile phones go through the full life cycle, sometimes referred to as partial product life cycles (Shaw et al. 2015).

\section{Other Electronic Products}

Lightweight, electronic items have been viewed as important drivers of stolen goods markets and theft levels. It was hypothesized that the theft of electronic goods increased over the period of study. MP3 players and cameras share a number of attributes with mobile phones - they are concealable, removable, widely available and enjoyable to own (Clarke 1999). However, somewhat surprisingly, these items were consistently stolen in less than 10 per cent of incidents. With the majority of mobile phone handsets now able to take photographs and play music this reduces the need for separate devices. The apparent low incidence of theft may therefore be because these items are not routinely carried on the person and/or due to a minimal resale value on the stolen goods market.

\section{The Role of Security}

The overriding message of the security hypothesis is that security improvements have driven falls in crime (Farrell et al. 2008). There is growing empirical evidence in relation to the 
effectiveness of vehicle and household security (Tseloni et al. 2014; Farrell, Tseloni and Tilley 2011); the same unfortunately cannot be said for personal security. There has been a relative lack of attention to the use and effectiveness of personal precautions (such as personal attack alarms) against victimization. The impact of security on the type of items stolen through theft and robbery is not easy to test empirically due to a lack of data. The increased securitization of the street (e.g. CCTV) may have had some impact on theft trends but again this is difficult to test.

In relation to mobile phone security, Farrell (2015) provides a comprehensive overview of mobile phone anti-theft measures adopted over the last two decades. These include blacklisting, reprogramming, "kill switches" and theft indices. The ability to block stolen mobile phones was introduced in the UK in 2003 and was intended to deny the benefits of theft to an offender by rendering the phone useless. However, handsets could still be unblocked relatively easily and cheaply (until the enactment of legislation banning this) thus the impact on theft levels may have been much smaller than anticipated. The slight reduction in the theft of mobile phones between 2004 and 2010 may have been a result of blocking stolen handsets and/or mobile phones entering the saturation phase of the consumer life cycle (Felson 1998). However, it seems this was relatively short-lived as changes in the market since 2010 , most notably the rise in popularity of Smartphones (Ofcom 2013), may have renewed interest in the market for mobile phones.

\section{Horizon Scanning}

Shifts in payment preferences and the availability of particular items may help explain trends in the theft of particular products. It is hypothesized that (without appropriate intervention) cash, purses/wallets, credit/debit cards and mobile phones will continue to occupy dominant 
positions (although perhaps alternating in their positioning) as the items most frequently stolen in theft from the person and robbery. With a tendency to carry cash in a purse or wallet the gap between these items is likely to remain relatively small.

The notion that vulnerability to theft can be 'designed out' of particular products is not new: "While technology can create new opportunities for theft and fraud, it can also be deployed to eliminate opportunities for these crimes" (Clarke, Kemper and Wyckoff 2001: 19). For this reason, manufacturers are best placed to foster and implement anti-theft design (Whitehead et al. 2008). Criminologists can contribute to these discussions (providing data and research findings) but ultimate responsibility must lie with those designing the products. This should be achieved through voluntary agreements, security standards and the use of risk assessment mechanisms (e.g. Project MARC, Armitage and Pease 2007; Newman 2012; Laycock 2004) via healthy and open dialogue with stakeholders (Clarke, Kemper and Wyckoff 2001; Kettlewell 2007; Armitage 2012). In doing so, potentially "troublesome tradeoffs" (Ekblom 2005) between security, user-friendliness and aesthetics are far easier to resolve. In relation to mobile phones, Farrell (2015) suggests more international co-ordination, political will and technical expertise are required to keep up with constantly evolving mobile technology and subsequent criminal opportunities.

\section{Limitations and Future Research}

There are a number of avenues for future research. A natural extension of this work would be to look at goods stolen through other crime types and in other countries. Fitzgerald and Poynton (2011) reported a shift toward the theft of cash in burglaries in New South Wales. This may indicate both crime type and international differences in items stolen that would constitute an interesting area for further research. Data relating to stolen goods from the US National Crime Victimization Survey (NCVS) could be used for this purpose. Cross-national and crime type 
comparisons would help ascertain whether "hotness" is a function of object desirability rather than accessibility on the person. More research is needed to test the security hypothesis and the effectiveness of personal security devices in relation to crimes against the person.

Unfortunately, it is not possible to identify where stolen goods are subsequently disposed of using CSEW data. Previous research suggests residential fences and network sales are popular methods of disposal (Schneider 2005). The increase in popularity of online auction sites since the late 1990s may have contributed to a shift in offender decision-making towards selecting goods that are difficult to identify and easy to dispose of through "eSelling" (Sutton 2010; Treadwell 2012). It would therefore be useful to consider other potential sources of data, for example offender interviews. This would provide a rich intelligence picture in relation to perpetrator motivations, techniques and stolen goods markets (Ekblom 2014b).

Future research may seek to examine the rate of theft for each product type, calculated as the number of products stolen per target at risk during a given time period. This would help determine whether the total number of targets in circulation contributes to the overarching crime problem (Clarke and Eck 2005; Smith and Clarke 2015). This research would require an appropriate data source to accurately determine the number of targets in circulation (proxy measures could be constructed for this purpose).

\section{$\underline{\text { Summary }}$}

Four hot products have been identified in relation to theft from the person and robbery victimization: cash; credit/debit cards; purses/wallets; and mobile phones. Taken collectively, the findings lend support to the hypothesis that the trend in theft and robbery is composed of two underlying trends: one which mirrors the more general decreases in crime, and one which 
reflects increased theft due to the greater availability of new, valuable goods (particularly mobile phones) that are attractive to thieves and/or carried on the person. Without the introduction (and subsequent popularity) of mobile phones the stolen goods landscape may have been rather different (Harrington and Mayhew 2001; Aebi and Linde 2012). 
Notes

1. A Smartphone is "a mobile phone capable of running general-purpose computer applications, now typically with a touch-screen interface and Internet access" (Oxford English Dictionary Online, 2015).

2. For further information relating to survey methodology there are a range of CSEW Technical Reports available online (http://discover.ukdataservice.ac.uk/).

3. If a respondent experiences more than one incident within the reference period a computer programme allocates the order of the Victimization Modules. Practically, this means the survey only collects limited details (through the short Victim Module) for incidents deemed as more common. Data concerning stolen goods is not collected within the short Victim Module. The analysis presented here is therefore restricted to respondents who reported items stolen and completed the long Victim Module where information was available regarding the month and year of victimisation.

4. Due to the non-continuous nature of the survey prior to 2000 , data is not available for three six-month periods: June through December 1994, 1996 and 1998.

5. Figure 2 shows only those items stolen in more than 15 per cent of incidents at any point over the period studied.

6. Contactless payment methods allow you to touch an enabled device or debit card to a reader to make a payment (currently a maximum value of £30). A signature or PIN number is not required. 


\section{$\underline{\text { References }}$}

Aebi, Marcelo F. and Antonia Linde. 2012. "Crime Trends in Western Europe according to Official Statistics from 1990 to 2007” in van Dijk, Jan J.M., Andromachi Tseloni and Graham Farrell, eds. The International Crime Drop: New Directions in Research, Hampshire: Palgrave Macmillan: 37-75.

Apple Inc. 2015. “iPhone 5s - Technical Specifications”. Retrieved April 24, 2015 (http://www.apple.com/uk/iphone-5s/specs/).

Armitage, Rachel and Ken Pease. 2007. "Predicting and Preventing the Theft of Electronic Products", European Journal on Criminal Policy and Research, 14(1): 1237.

Armitage, Rachel. 2012. "Making a Brave Transition from Research to Reality" in Ekblom, Paul, ed. Design Against Crime: Crime Proofing Everyday Products. Crime Prevention Studies, Volume 27, London: Lynne Rienner Publishers Inc.: 65-85.

Barker, Mary, Jane Geraghty, Barry Webb and Tom Key. 1993. "The Prevention of Street Robbery", Crime Prevention Unit Series Paper 44, London: Home Office.

BBC News. 5th January 2000. “Mobile Phone Sales Surge”. Retrieved January 14, 2014 (http://news.bbc.co.uk/1/hi/business/591443.stm).

Budd, Tracey. 1999. "Burglary of Domestic Dwellings: Findings from the British Crime Survey”, Home Office Research Bulletin, Issue 4/99 London: Home Office. 
Chaplin, Rupert, John Flatley and Kevin Smith. 2011. Crime in England and Wales 2010/11: Findings from the British Crime Survey and Police Recorded Crime, 2nd Edition, London: Home Office.

CITEworld, 10 ${ }^{\text {th }}$ May 2013. "Smartphone thefts are driving an epidemic of violent crime". Retrieved January 14 2014

(http://www.citeworld.com/article/2115062/mobile-byod/smartphone-theft-

epidemic.html).

Clarke, Ronald V. 1999. "Hot Products: Understanding, Anticipating and Reducing Demand for Stolen Goods", Police Research Series Paper 112. Policing and Reducing Crime Unit. Research Development and Statistics Directorate, London: Home Office.

Clarke, Ronald V. and John E. Eck. 2005. Crime Analysis for Problem Solvers in 60 Small Steps, Washington: U.S. Department of Justice.

Clarke, Ronald V., Rick Kemper and Laura Wyckoff. 2001. "Controlling Cell Phone Fraud in the US: Lessons for the UK 'Foresight' Prevention Initiative", Security Journal, 14(1): 7-22.

Cohen, Lawrence E. and Marcus Felson. 1979. "Social Change and Crime Rates and Trends: A Routine Activity Approach", American Sociological Review, 44: 588-608. 
Computer Networking and Telecommunications Research. 2013. Retrieved January 14, 2014 (http://www.cntr.salford.ac.uk/comms/mobile.php).

Ekblom, Paul. 2005. "How to Police the Future: Scanning for Scientific and Technological Innovations which Generate Potential Threats and Opportunities in Crime, Policing and Crime Reduction" in Smith, Melissa J. and Nick Tilley, eds. Crime Science: New Approaches to Preventing and Detecting Crime, Devon: Willan: 27-55.

Ekblom, Paul. 2014a. "Design and Security" in Gill, Martin, eds. Handbook of Security, Hampshire: Palgrave Macmillan: 133-156.

Ekblom, Paul. 2014b. "Securing the Knowledge" in Gill, Martin, eds. Handbook of Security, Hampshire: Palgrave Macmillan: 487-515.

Farrell, Graham. 2015. "Preventing Phone Theft and Robbery: the Need for Government Action and International Coordination", Crime Science 4(4).

Farrell, Graham, Nick Tilley, Andromachi Tseloni and Jen Mailley. 2008. "The Crime Drop and the Security Hypothesis”, British Society of Criminology Newsletter, 62: 1721.

Farrell, Graham, Andromachi Tseloni and Nick Tilley. 2011. "The Effectiveness of Vehicle Security Devices and their Role in the Crime Drop". Criminology and Criminal Justice, 11(1): 21-35. 
Felson, Marcus. 1997. "Technology, Business, and Crime” in Felson, Marcus and Ronald V. Clarke, eds. Business and Crime Prevention, New York: Criminal Justice Press: 81-96.

Felson, Marcus. 1998. Crime and Everyday Life, 2nd Edition, Thousand Oaks, CA: Sage.

Financial Fraud Action UK. 2012. Fraud the Facts 2012: The Definitive Overview of Payment Industry Fraud and Measures to Prevent It, London: FFA UK.

Fitzgerald, Jacqueline and Suzanne Poynton. 2011. "The Changing Nature of Objects Stolen in Household Burglaries", Crime and Justice Statistics Bureau Brief No. 62, Sydney: NSW Bureau of Crime Statistics and Research.

Gale, Julie-Anne and Timothy Coupe. 2005. "The Behavioural, Emotional and Psychological Effects of Street Robbery on Victims", International Review of Victimology, 12, pp. 1-22.

Gentry, Kendra. 2015. “Apple Picking: The Rise of Electronic Device Thefts in Boston Subways" in Ceccato, Vania and Andrew Newton, eds. Safety and Security in Transit Environments: An Interdisciplinary Approach: 39-55.

Hardison Walters, Jennifer, Andrew Moore and Marcus Berzofsky. 2013. Household Burglary, 1994-2011, Washington: Bureau of Justice Statistics. 
Harrington, Victoria and Pat Mayhew. 2001. "Mobile Phone Theft", Home Office Research Study 235, London: Home Office.

Home Office. 2014. Reducing Mobile Phone Theft and Improving Security, London: Home Office.

Home Office. 2015. Home Office Counting Rules for Recorded Crime, London: Home Office.

Home Office - Crime and Criminal Justice Unit and Office of Population Censuses and Surveys. Social Survey Division, British Crime Survey, 1994 [computer file]. Colchester, Essex: UK Data Archive [distributor], May 2000. SN: 3591, http://dx.doi.org/10.5255/UKDA-SN-3591-1.

Home Office - Research and Statistics Directorate and Social and Community Planning Research, British Crime Survey, 1996 [computer file]. Colchester, Essex: UK Data Archive [distributor], January 2007. SN: 3832, http://dx.doi.org/10.5255/UKDA-SN3832-1.

Home Office - Research and Statistics Directorate and Social and Community Planning Research, British Crime Survey, 1998 [computer file]. Colchester, Essex: UK Data Archive [distributor], January 2007. SN: 4081, http://dx.doi.org/10.5255/UKDA-SN4081-1. 
Home Office - Research, Development and Statistics Directorate and BMRB. Social Research, British Crime Survey, 2001 [computer file]. Colchester, Essex: UK Data Archive [distributor], March 2012. SN: 4786, http://dx.doi.org/10.5255/UKDA-SN4786-2.

Home Office - Research, Development and Statistics Directorate and BMRB. Social Research, British Crime Survey, 2001-02 [computer file]. Colchester, Essex: UK Data Archive [distributor], January 2008. SN: 4787, http://dx.doi.org/10.5255/UKDA-SN4787-1.

Home Office - Research, Development and Statistics Directorate and BMRB. Social Research, British Crime Survey, 2002-03 [computer file]. Colchester, Essex: UK Data Archive [distributor], October 2007. SN: 5059, http://dx.doi.org/10.5255/UKDA-SN5059-1.

Home Office - Research, Development and Statistics Directorate and BMRB. Social Research, British Crime Survey, 2003-04 [computer file]. Colchester, Essex: UK Data Archive [distributor], October 2007. SN: 5324, http://dx.doi.org/10.5255/UKDA-SN5324-1.

Home Office - Research, Development and Statistics Directorate and BMRB. Social Research, British Crime Survey, 2004-05 [computer file]. Colchester, Essex: UK Data Archive [distributor], October 2007. SN: 5347, http://dx.doi.org/10.5255/UKDA-SN5347-1. 
Home Office - Research, Development and Statistics Directorate and BMRB. Social Research, British Crime Survey, 2005-06 [computer file]. Colchester, Essex: UK Data Archive [distributor], December 2008. SN: 5755, http://dx.doi.org/10.5255/UKDASN-5543-1.

Home Office - Research, Development and Statistics Directorate and BMRB. Social Research, British Crime Survey, 2006-07 [computer file]. Colchester, Essex: UK Data Archive [distributor], December 2008. SN: 5755, http://dx.doi.org/10.5255/UKDA$\underline{\mathrm{SN}-5755-1}$.

Home Office - Research, Development and Statistics Directorate and BMRB. Social Research, British Crime Survey, 2007-08 [computer file]. Colchester, Essex: UK Data Archive [distributor], March 2009. SN: 6066, http://dx.doi.org/10.5255/UKDA-SN6066-1.

Home Office - Research, Development and Statistics Directorate and BMRB. Social Research, British Crime Survey, 2008-09 [computer file]. Colchester, Essex: UK Data Archive [distributor], January 2010. SN: 6367, http://dx.doi.org/10.5255/UKDA-SN6367-1.

Home Office - Research, Development and Statistics Directorate and BMRB. Social Research, British Crime Survey, 2009-10 [computer file]. Colchester, Essex: UK Data Archive [distributor], March 2012. SN: 6627, http://dx.doi.org/10.5255/UKDA-SN6627-2. 
Home Office - Research, Development and Statistics Directorate and TNS-BMRB, British Crime Survey, 2010-11 [computer file]. Colchester, Essex: UK Data Archive [distributor], January 2012. SN: 6937, http://dx.doi.org/10.5255/UKDA-SN-6937-1.

Kaplankiran, Tulay, Jen Mailley, Shaun Whitehead and Graham Farrell. 2008. "Mobile Phone Reprogramming: Its Extent and Prevention", Crime Prevention and Community Safety, 10: 271-279.

Kettlewell, Lee. 2007. Report on Government Office for London Personal Robbery Project, January-November 2007, London: Government Office for London.

Kock, Egmont, Tim Kemp and Bernard Rix. 1996. "Disrupting the Distribution of Stolen Electrical Goods", Crime Detection and Prevention Series Paper 69, London: Home Office.

Laycock, Gloria. 2004. "The U.K. Car Theft Index: An Example of Government Leverage" in Maxfield, Michael and Ronald V. Clarke, eds. Understanding and Preventing Car Theft-Crime Prevention Studies, Volume 17: 25-43.

Mailley, Jen, Shaun Whitehead and Graham Farrell. 2006. "Progress and Prospects in the Prevention of Mobile Phone Theft", Justice of the Peace, 170(22): 404-407.

Mailley, Jen, Roni Garcia, Shaun Whitehead and Graham Farrell. 2008. "Phone Theft Index", Security Journal, 21: 212-227. 
Nelson, Diana, Lisa Collins and Frances Gant. 2002. The Stolen Property Market in the Australian Capital Territory, Australia: Australian Institute of Criminology.

Newman, Graeme R. 2012. "A Market Approach to Crime Prevention” in Ekblom, Paul, ed. Design Against Crime: Crime Proofing Everyday Products, Crime Prevention Studies, Volume 27, London: Lynne Rienner Publishers, Inc.: 87-105.

Ofcom. 2013. Communications Market Report 2013. Retrieved January 142014 (http://stakeholders.ofcom.org.uk/binaries/research/cmr/cmr13/2013_UK_CMR.pdf).

Office for National Statistics (ONS). 2013. Crime Statistics, Focus on Property Crime, 2011/12, London: ONS.

Office for National Statistics (ONS). 2015. Overview of Internet Retail Sales in 2014.

$\begin{array}{lll}\text { Retrieved } & \text { February } & 2616\end{array}$

(http://webarchive.nationalarchives.gov.uk/20160105160709/http://www.ons.gov.uk/ ons/rel/rsi/retail-sales/december-2014/sty-overview-of-internet-retail-sales-in2014.html).

Office for National Statistics (ONS). 2015. Crime in England \& Wales, year ending March 2015 - Appendix tables, London: ONS.

Oxford English Dictionary Online. 2015. Oxford University Press. 
Palmer, Emma J., Angela Holmes and Clive R. Hollin. 2002. "Investigating Burglars'

Decisions: Factors Influencing Target Choice, Method of Entry, Reasons for Offending, Repeat Victimisation of a Property and Victim Awareness", Security Journal, 15: 7-18.

Payments Council. 2010. The Way We Pay 2010: the UK's Payment Revolution, London: Payments Council.

Pires, Stephen F. and Clarke, Ronald V. 2011. "Sequential Foraging, Itinerant Fences and Parrot Poaching in Bolivia”, British Journal of Criminology, 51(2): 314-335.

Roman, John and Aaron Chalfin. 2007. 'Is there an iCrime Wave?' Research Report, Washington: Urban Institute.

Rosenfeld, Richard. 2009. "Crime is the Problem: Homicide, Acquisitive Crime and Economic Conditions”, Journal of Quantitative Criminology, 25: 287-306.

Schneider, Jacqueline L. 2005. "Stolen-Goods Markets: Methods of Disposal”, British Journal of Criminology, 45: 129-140.

Shaw, Oliver, Nick Morgan, Irina Mineva, Jacqueline Hoare and Rachel Stevenson. 2015. "Crime and the Value of Stolen Goods", Home Office Research Report 81, London: Home Office. 
Smith, Jonathan. 2003. "The Nature of Personal Robbery”, Home Office Research Study 254, London: Home Office.

Smith, Brian, T. and Ronald V. Clarke. 2015. "Shoplifting of Everyday Products that Serve Illicit Drug Uses", Journal of Research in Crime and Delinquency, 52(2): 245269.

Sutton, Michael. 1995. "Supply by Theft: Does the Market for Second-hand Goods Play a Role in Keeping Crime Figures High?” British Journal of Criminology, 35(3): 400-416.

Sutton, Michael. 2010. Stolen Goods Markets, Problem Oriented Policing Guide No. 57. US National Institute of Justice COPS Programme.

Thompson, Rebecca. 2014. "Understanding Theft from the Person and Robbery of Personal Property Victimisation Trends in England and Wales, 1994-2010/11.” PhD thesis, Nottingham Trent University, Nottingham.

Treadwell, James. 2012. "From the Car Boot to Booting it Up? eBay, Online Counterfeit Crime and the Transformation of the Criminal Marketplace”, Criminology and Criminal Justice, 12: 175-191.

Tseloni, Andromachi, Rebecca Thompson, Louise Grove, Nick Tilley and Graham Farrell. 2014. "The Effectiveness of Burglary Security Devices”, Security Journal. 
UK Data Service. 2016. General Lifestyle Survey. Retrieved May 172016 (https://discover.ukdataservice.ac.uk/series/?sn=200019).

Van Dijk, Jan J.M., Robert Manchin, John van Kesteren, Gergely Hideg and Sami Navala. 2005. "The Burden of Crime in the EU", Research Report: A Comparative Analysis of the European Survey of Crime and Safety 2005, Europe: Gallup.

Van Dijk, Jan J.M., John van Kesteren and Paul Smit. 2007. Criminal Victimisation in International Perspective: Key Findings from the 2004-2005 ICVS and EU-ICS, The Hague: WODC.

Van Dijk, Jan J.M., Andromachi Tseloni and Graham Farrell. 2012. The International Crime Drop: New Directions in Research, Hampshire: Palgrave Macmillan.

Wellsmith, Melanie and Amy Burrell. 2005. "The Influence of Purchase Price and Ownership Levels on Theft Targets: The Example of Domestic Burglary", British Journal of Criminology, 45: 741-764.

Whitehead, Shaun, Jen Mailley, Ian Storer, John McCardle, George Torrens and Graham Farrell. 2008. "IN SAFE HANDS: A Review of Mobile Phone Anti-theft Designs", European Journal on Criminal Policy and Research, 14: 39-60.

Zimring, Franklin. 2007. The Great American Crime Decline, New York: Oxford University Press. 


\section{$\underline{\text { Appendix }}$}

\section{$\underline{\text { A1. Code Frame Changes }}$}

Over the period studied, changes were made to the categories in "what was stolen" variable - this was, for the most part, to include more categories of stolen goods and improve the accuracy of recording. Where changes to this variable fell within a sweep, two sets of stolen goods variables are recorded within one data set, often with a large number of missing cases on each. The reason for this overlap lies in survey procedure where, in some cases, the coding frame was altered midway through the survey period. In order to combat this data was combined across data sets to create an overarching set of comparable categories which accounted for most cases and most stolen goods. All four hot products listed have been coded as such throughout the period of analysis and the author feels it is unlikely these items would have been mistaken for anything else or incorrectly labeled. 
Figure 1: Figure showing trends in CSEW incidence rates from 1993 to 2011/12 (Office for National Statistics 2015)

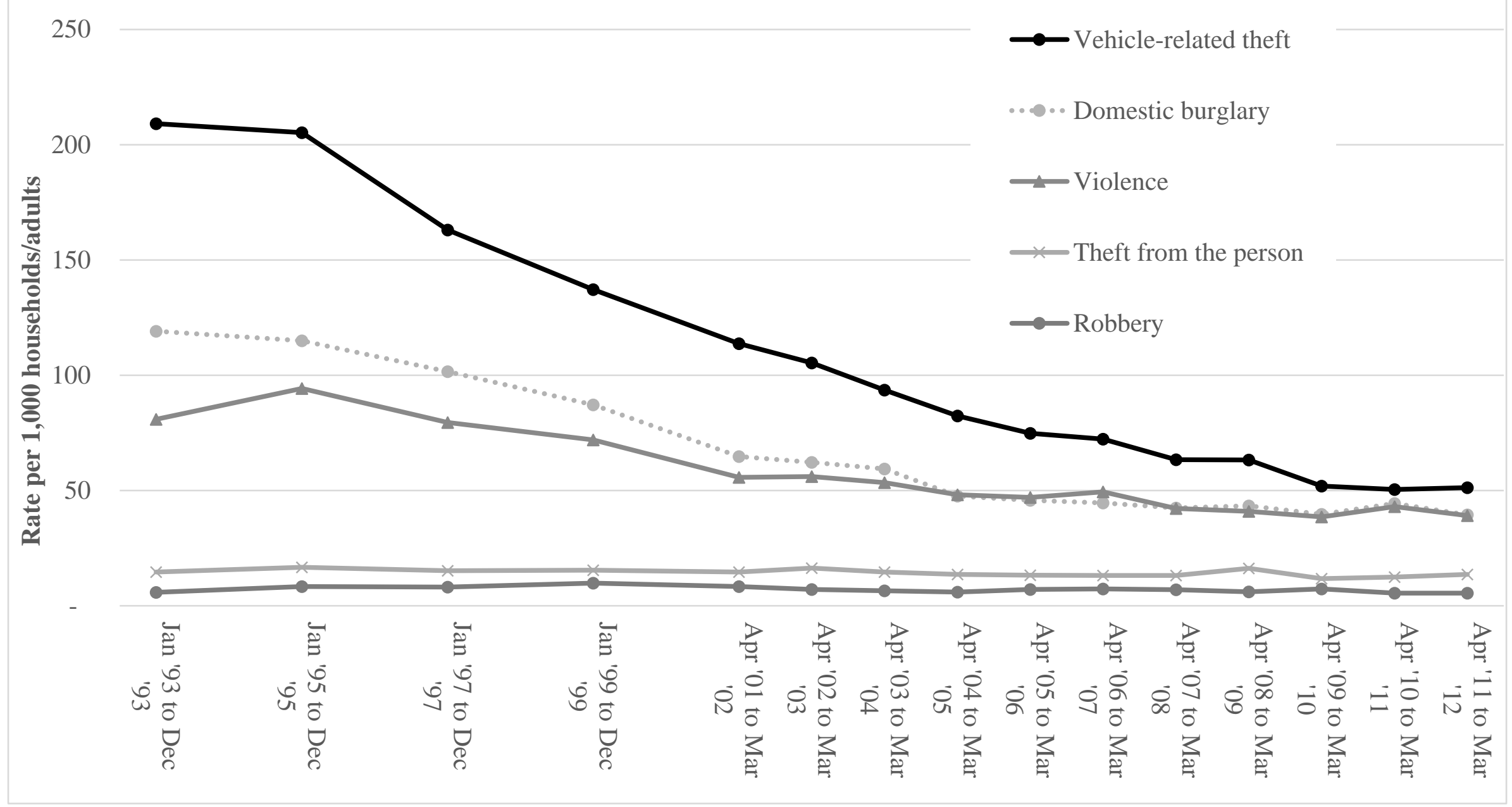


Figure 2: Proportion of theft from the person and robbery incidents where selected goods were stolen by six-month period (January

\section{3 - June 2010) $)^{+}$}

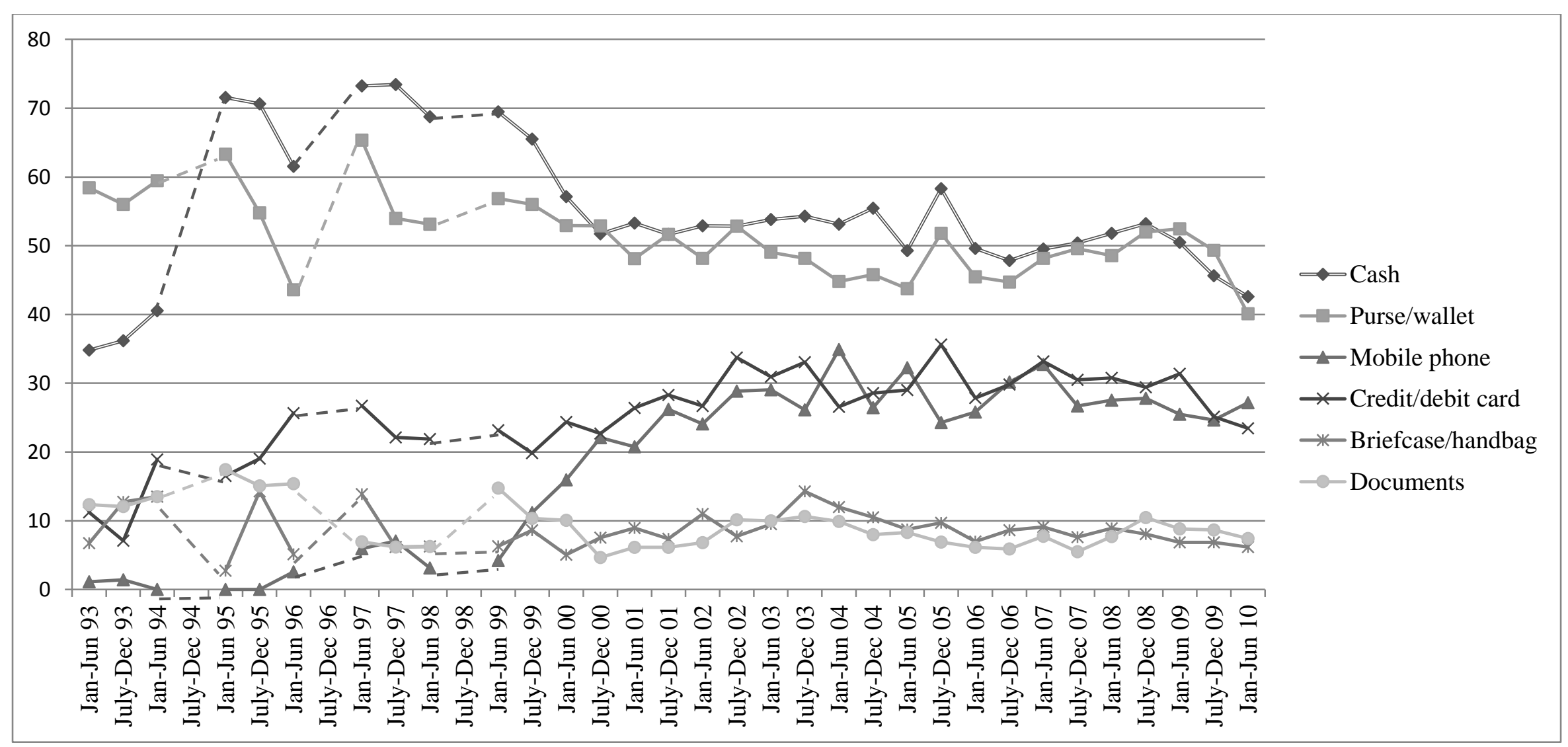

${ }^{+}$Dotted lines refer to missing data when the CSEW was not a continuous survey 
Table 1: Percentage change in particular items stolen comparing six-month periods in 1996 and 2010 (January-June)

\begin{tabular}{l|r} 
Item & \% change 1996 to 2010 \\
\hline Cash & $-18.95 \sim$ \\
\hline Purse/wallet & $-3.47 \sim$ \\
\hline Credit/debit card & $-2.18^{*}$ \\
\hline Mobile phone & $24.6 \sim$ \\
\hline Briefcase/handbag & 1.04 \\
\hline Documents & $-7.97 \sim$ \\
\hline Checkbooks & $-11.59 \sim$ \\
\hline Jewelry/watches & $5.56 \sim$ \\
$* 0.01<$ p-value $\leq 0.05$ & \\
$\sim$ p-value $\leq 0.01$ &
\end{tabular}


Figure 3: Comparing the proportion (\%) of theft from the person and robbery incidents where selected items were stolen over a sixmonth period in 1996 with 2010

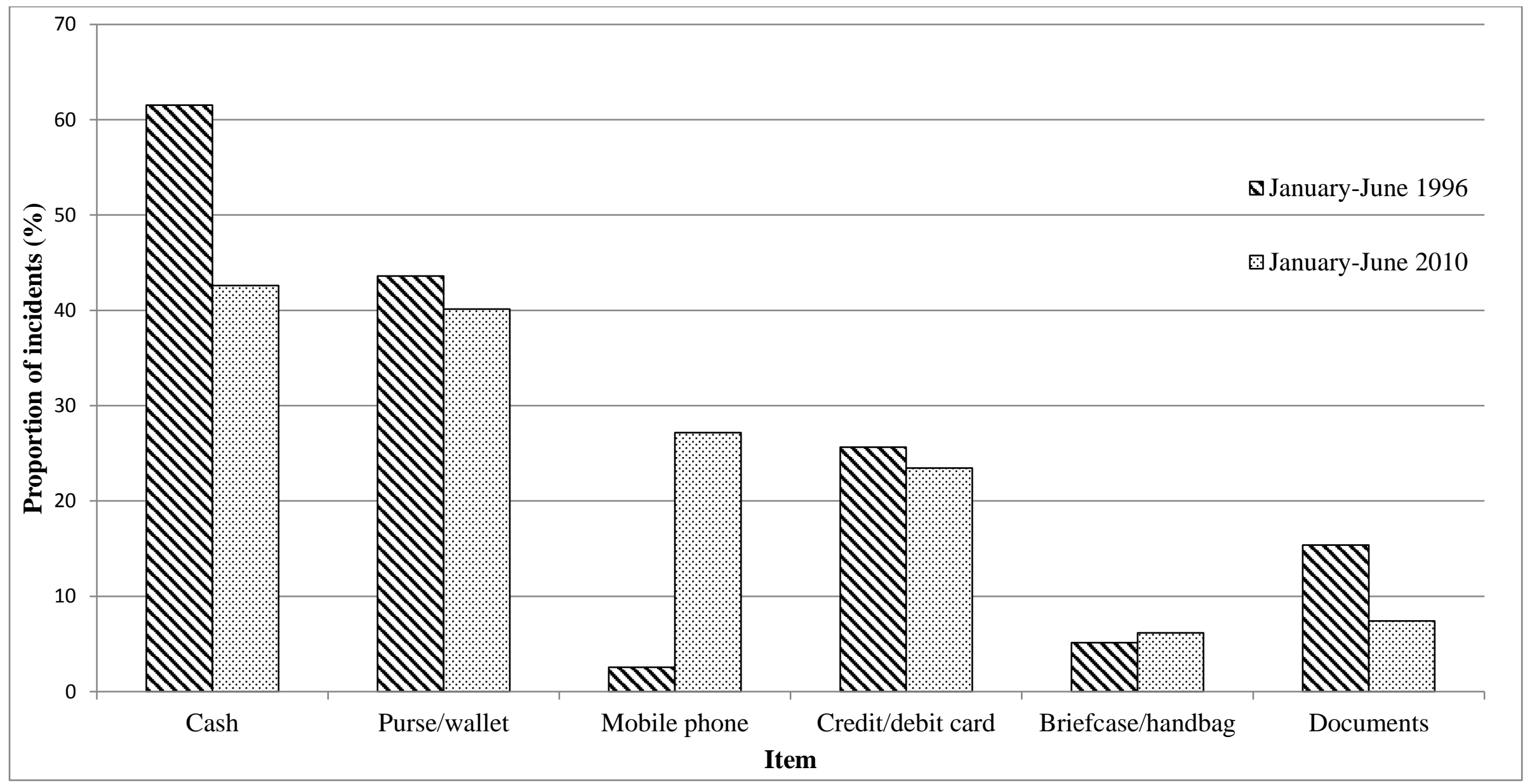


Figure 4: Mobile phone ownership against the proportion of theft from the person and robbery incidents where a mobile phone was stolen (1993-2009)

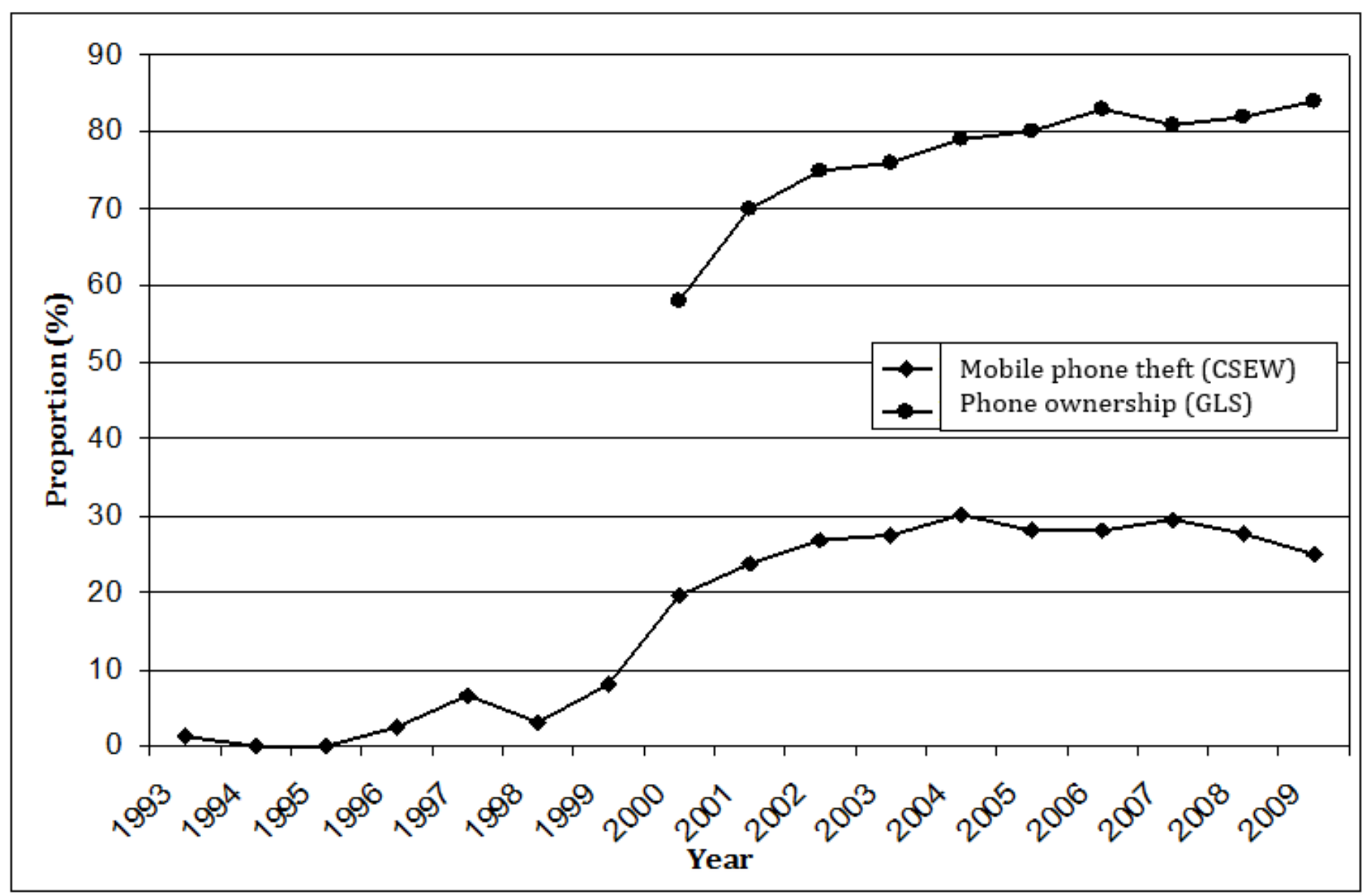

